\title{
Lymphoid Tissue in the Lizard
}

\author{
By \\ Masahiko Kotani \\ From the Third Division of Anatomical Institute, Faculty of \\ Medicine, Kyoto University, Kyoto \\ Three Plates (13 Figures) \\ The present paper reports a study of lymphoid tissue in lizards \\ and describes some of the characteristics of their lymphoid tissue. \\ Lymphoid tissue in other reptiles was studied in turtles by $\mathrm{Kondo}$ \\ (1937) and Mori (1941) and in snakes by Mori (1941), T a k a w a \\ (1943) and Kotani (1959). Recently, Ki h a r a (1954) subdivided \\ the lymphoid tissue, in general, into two: the subepithelial and the
} submesothelial lymphoid tissue.

\section{Materials and Methods}

Japanese native lizards, Eumeces latiscutatus (Hallowell), were used. The tissues from these animals were fixed in $10 \%$ formalin, embedded in celloidin and sectioned at $12 \mu$. The observations were made on sections stained with hematoxylin and eosin. Before fixation, the lymphatics in some specimens, were filled with $0.5 \%$ Berlin Blue solution by the direct injection method.

\section{Observations}

A) Submesothelial lymphoid tissue

1) Lymph nodule on the wall of the thoracic duct (Fig. 1)

A triangular lymph nodule appeared on the wall of the left thoracic duct. A corner of the triangle projects deeply into the lumen of the lymphatic trunk. The free surface of this nodule was covered with a single layer of flat mesothelial cells. The base of the triangle was clearly defined by the underlying connective tissue and was about $215 \mu$ in length. 
The height of the triangle was about $50 \mu$.

2) Lymph nodule on the wall of the lymphatics of the small intestine (Fig. 2)

Five lymph nodules appeared on the wall of the lymphatics between the internal circular and the external longitudinal muscular layer in 120 continuous sections which were cut at $12 \mu$. Two nodules were spherical and the two others were disk-like. The last one was triangular. One of the ball-like nodules was about $73 \mu$ in diameter and the other was about $75 \mu$. One of the disk-like nodules was about $180 \mu$ in diameter and $29 \mu$ in thickness. The other was about $145 \mu$ in diameter and $23 \mu$ in thickness. The triangular nodule was about $87 \mu$ in length at its base and $43.5 \mu$ in height.

These lymph nodules were all projecting into the lymphatic lumen and the flat mesothelial cells were lining the free surface of the projecting parts of these nodules. Arteriola provided with cuboid or slightly higher mesothelial cells passed through the center or the periphery of four nodules.

3) Lymph infiltrations in the ganglion (Fig. 3)

A few numbers of lymph infiltrations appeared in a ganglion, which was located at the dorsal of the oesophagus at the level of the heart. These infiltrations might belong to the category of the submesothelial lymphoid tissue of vein.

4) Lymph nodule in the kidney (Fig. 4)

A nodule appeared in the kidney immediately under the fibrous capsule in 20 continuous sections. It was relatively distinct, having a clear border line separating it from the glandular tissue. This nodule might be the one which belongs to the submesothelial lymphoid tissue of the vein.

B) Subepithelial lymphoid tissue

1) Oesophagus (Fig. 5, 6)

In the upper part of the oesophagus 24 lymph nodules and 9 lymph infiltrations in 200 continuous sections, and in the lower part 2 lymph nodules in 25 sections were found. They were mainly in the lamina propria. Some of them extended through the muscularis mucosae into the submucous layer. The mucous fold in the upper part, and the secondary fold in the lower part, containing the lymph nodule, were occasionally 
larger than those which were free from the lymphoid tissue.

It was conspicuous to note that the common cylindrical ciliated epithelial cells changed their height considerably and flattened in a part of the surface of the lymph nodule or the lymph infiltration. Moreover, the boundaries between the adjacent cells were indistinct and a number of lymphocytes were penetrating the epithelium through this point.

The base of the lymph nodule was immediately surrounded by a dish-like network of the lymphatics.

2) Stomach (Fig. 7, 8)

Four lymph infiltrations occurred in the narrow spaces of the lamina propria between the long tubular glands and the muscularis mucosae in 10 continuous sections of the stomach proper.

In 10 continuous sections of the pylorus 8 lymph infiltrations filled the narrow propria between the relatively short tubular mucous glands and the muscularis mucosae.

3) Small intestine (Fig. 9, 10, 11)

In 15 continuous sections of the small intestine of a lizard, 4 lymph nodules and 3 lymph infiltrations were found in the lamina propria of the mucous fold. The periphery of these lymphoid tissues were distinct, being separated from the submucous layer by the muscularis mucosae. A few lymphocytes had penetrated and disfigured the epithelium covering the lymphoid tissue.

In 15 continuous sections of the small intestine of an other lizard, 5 lymph nodules and 2 lymph infiltrations appeared in the lamina propria. It was particularly noted that a nodule had occurred resembling the secondary nodule. This nodule was composed of an outer dark-stained portion and a lighter center portion. The pale-stained center portion was spherical and its diameter was about $48 \mu$. This area, without its core, consisted mainly of medium-sized lymphocytes. A few small lymphocytes were scattered among them. The core of the pale-stained portion was sparse in cells. A few large cells and a few small cell fragments were investigated in this place.

The outer dark-stained portion consisting of small lymphocytes was thin and surrounded the periphery of the epithelial side of the lighter center area. The periphery of the opposit side of the center area was lacking in the dark-stained layer 
but was marked with the surrounding, densely packed connective tissue.

4) Large intestine (Fig. 12)

Lymphocytes diffusely infiltrated in the lamina propria of the large intestine. Especially in 6 parts in 15 continuous sections they aggregated relatively close.

5) Liver (Fig. 13)

Three lymph infiltrations occurred in the interlobular connective tissue around the bile duct and the portal vein. Lymphocytes were wandering in the cuboid or slightly higher epithelium beyond the basal membrane. At the same time a few lymphocytes migrated immediately under the mesothelium of the portal vein accompanied by the bile duct.

\section{Conclusion}

Submesothelial and subepithelial lymphoid tissues in lizards were investigated in many places and their characteristics were described. The fact that a secondary-nodule-like structure occurred in the small intestine was particularly interesting in regards to the problem of the evolution of lymphoid tissues.

\section{Acknowledgments}

I wish to express my hearty thanks to Prof. Dr. $\mathrm{H}$. $\mathrm{N}$ is h i$\mathrm{m} u \mathrm{ra}$ for his encouragement and to Emeritus Prof. Dr. T. Kih a ra for his criticisms through out this work.

\section{Literature cited}

Kih a r a, T. 1954: Verteilung und Entwicklung des lymphatischen Gewebes. (Japanese) Berichte des hämatologischen Symposiums, Nr. 6, s. 1-44. Osaka.

Kondo, M. 1937: Lymphgefässe und lymphatische Apparate der Schildkröte (Clemmys Japonica). (Japanese) Kyoto Igaku Z., Bd. 34, No. 8, s. 1-15.

Kota n i, M. 1959: Lymphgefässe, lymphatische Apparate und extravaskuläre Saftbahnen der Schlange (Elaphe quadrivirgata Boie). Acta Scholae Med. Universit. Kyoto, Vol. 36, Fasc. 2, s. 121-171.

Mori, K. 1941: Ueber die Herkunft der in der Lymphe auftretenden Zellen bei Schlange, Schildkröte und Ente. Acta Scholae Med. Universit. Kyoto, Vol. 24, Fasc. 1, s. 55-66.

T a k a w a, O. 1943: Vorkommen des lymphatischen Apparates im Venensystem und Differenzierung des Iymphatischen Apparates des Venensystems von dem des Lymphgefässsystems. (Japanese) Kyoto Igaku Z., Bd. 40, No. 4, s. 363-395. 


\section{Explanation of figures}

\section{Plate I}

Fig. 1. A triangular lymph nodule projects into the lumen of a lymphatic trunk. A, left aorta. Th, left thoracic duct surrounding the left aorta. The free surface of this nodule is covered with a layer of flat mesothelial cells. Hematoxylineosin stain. $430 \times$.

Fig. 2. A part of the small intestine. Mi, internal circular muscular layer. Me, external longitudinal muscular layer. A spherical lymph nodule projects into the lumen of a lymphatic vessel between two muscular layers. A arteriola provided with the cuboid mesothelial cells can be seen near the center of this nodule. The free surface of the nodule is covered with the flat lymphatic mesothelium. Hematoxylin-eosin stain. $430 \times$.

\section{Plate II}

Fig. 3. Cross section through the oesophagus, the ganglion and the back wall of the body. A large number of lymphocytes infiltrate among the ganglion cells. Hematoxylin-eosin stain. $225 \times$.

Fig. 4. A part of the kidney. A lymph nodule is seen between the fibrous capsule and the glandular tissue. Hematoxylin-eosin stain. $320 \times$.

Fig. 5. Cross section through the upper part of the oesophagus. A lymph nodule appears in the lamina propria of a fold. A few lymphocytes penetrate the epithelium through the short epithelial cell part. The peripheral margin of the nodule is surrounded with a lymphatic vessel filled with $0.5 \%$ Berlin Blue solution (Ly). Hematoxylin-eosin stain. $275 \times$.

Fig. 6. Cross section through the lower part of the oesophagus. A lymph nodule are indicated in the lamina propria of a larger secondary fold in comparison with the others which are free from the lymphoid tissue. The lymphocytes penetrate the epithelium through its thin part. 0.5\% Berlin Blue solution was injected into the lymphatics (Ly). Hematoxylin-eosin stain. $275 \times$.

Fig. 7. Cross section through a part of the stomach proper. Two lymph infiltrations fill the spaces between the base of the tubular glands and the muscularis mucosae. Hematoxylin-eosin stain. $380 \times$.

Fig. 8. Cross section through a part of the pylorus. Lymph infiltrations fill the narrow spaces between the mucous glands and the muscularis mucosae. Hematoxylin-eosin stain. $265 \times$.

\section{Plate III}

Fig. 9. Cross section through a part of the small intestine. A lymph nodule occurs in the lamina propria. Lymphocytes penetrate the epithelium. Hematoxylin. eosin stain. $265 \times$.

Fig. 10. Cross section through a part of the small intestine. Two continuous lymph nodules can be seen in the lamina propria. The left nodule is composed of an 
outer thin dark-stained portion and a spherical lighter center portion. Hematoxylin-eosin stain. $275 \times$.

Fig. 11. Enlargement of the left nodule in Fig. 10. In the core of the spherical palestained portion consisting mainly of medium-sized lymphocytes, a large cell and a few cell fragments are observed. The lighter-stained portion is lacking the outer dark-stained portion on the side of the muscularis mucosae. $960 \times$.

Fig. 12. Cross section of a part of the large intestine. Lymph infiltration in the lamina propria is shown. The epithelium is torn off. Hematoxylin-eosin stain. $360 \times$.

Fig. 13. A part of the liver. Lymph infiltration occurs around the bile duct and the accompanying portal vein. Hematoxylin-eosin stain. $320 \times$. 
Plate I

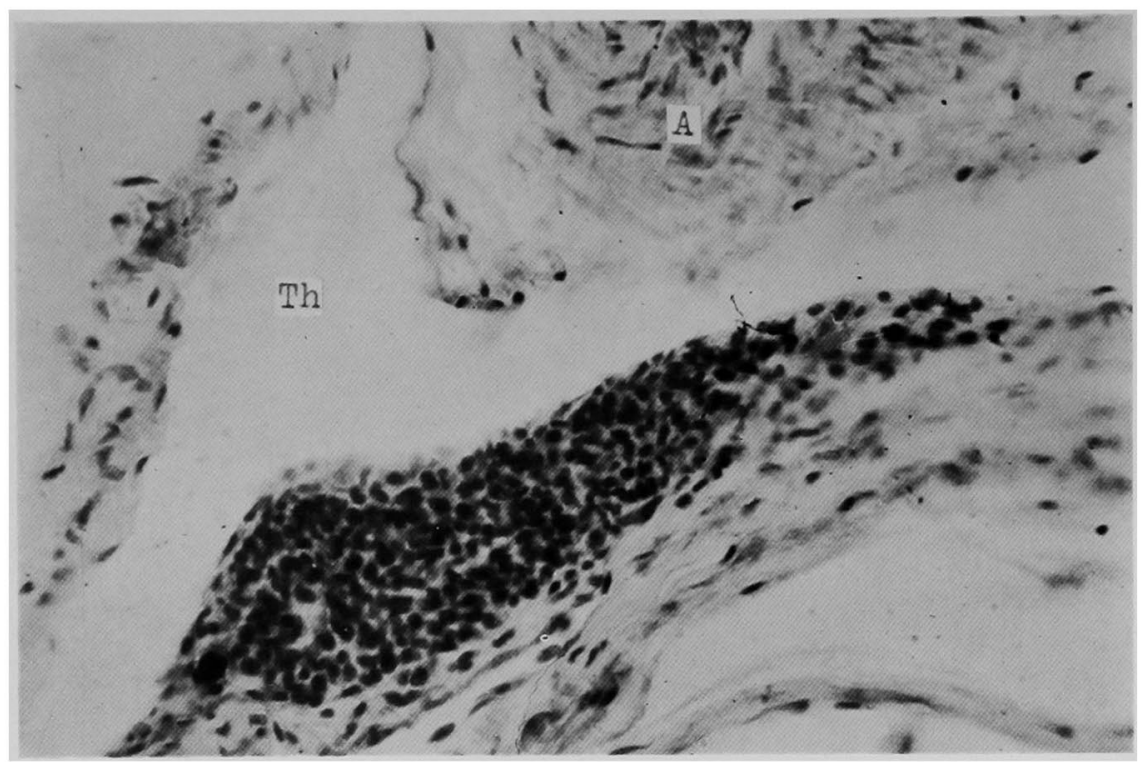

Fig. 1

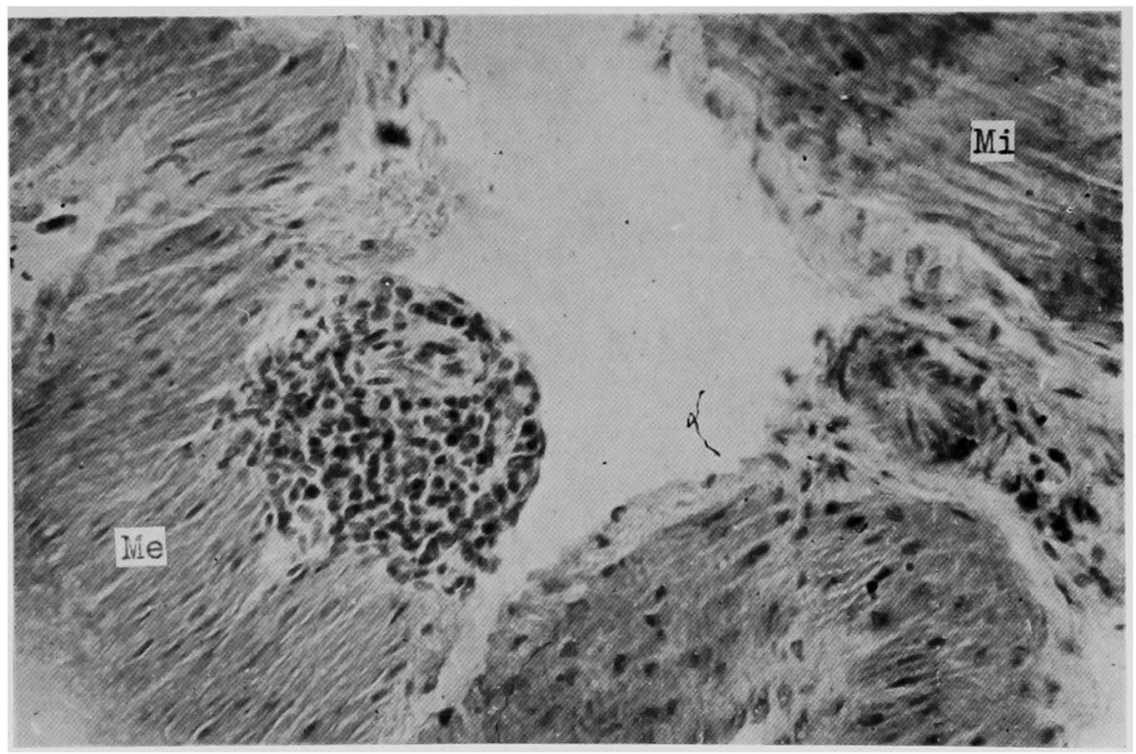

Fig. 2

M. Kotani 
Plate II

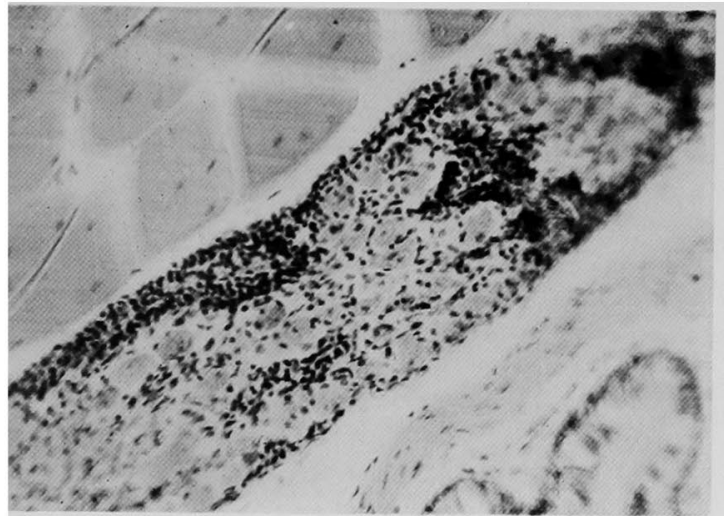

Fig. 3

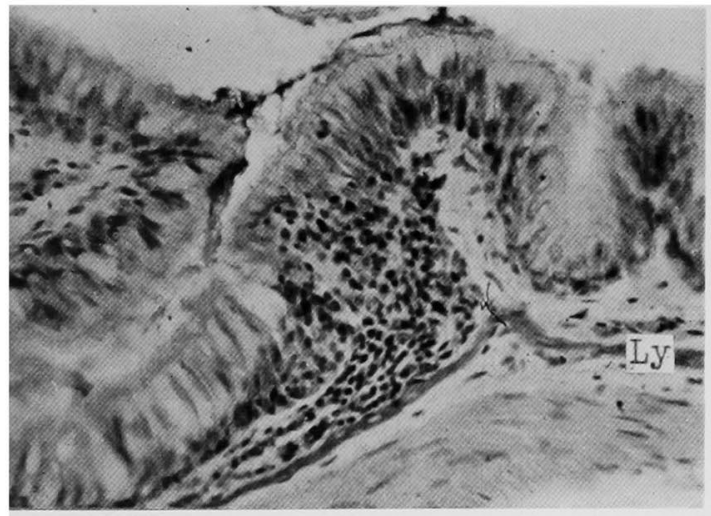

Fig. 5

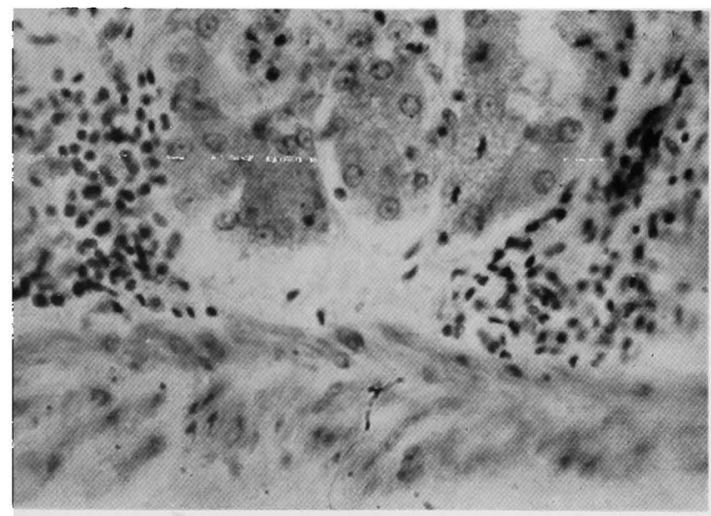

Fig. 7

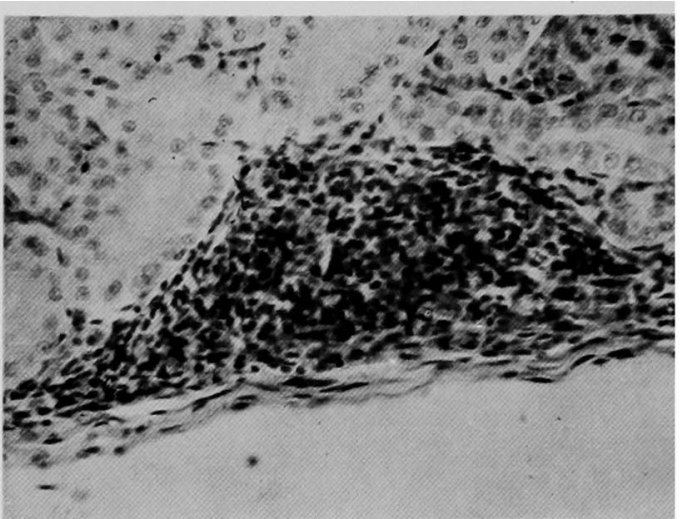

Fig. 4

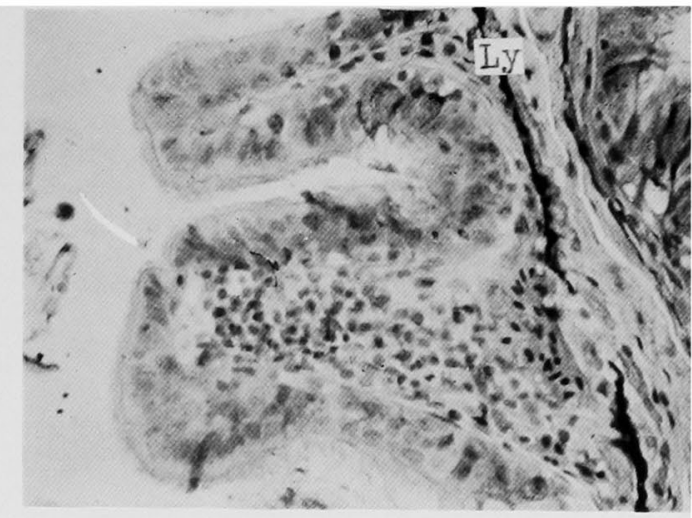

Fig. 6

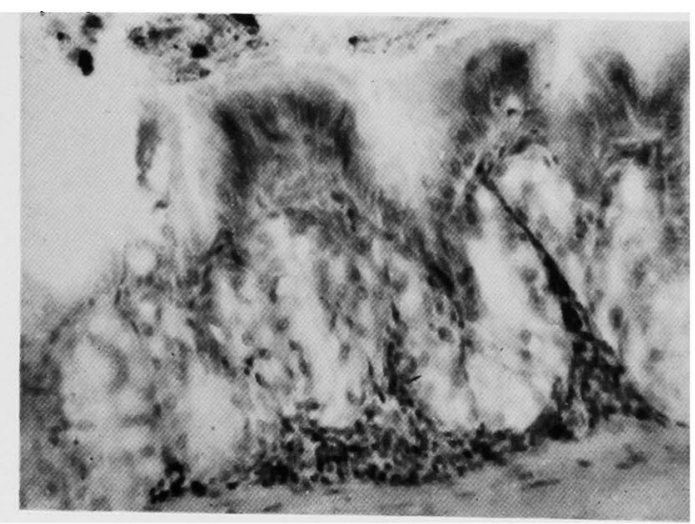

Fig. 8

M. Kotani 
Plate III

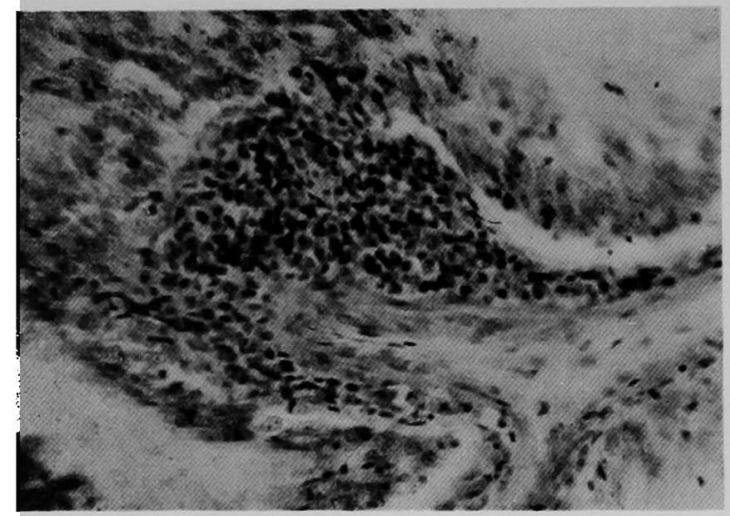

Fig. 9

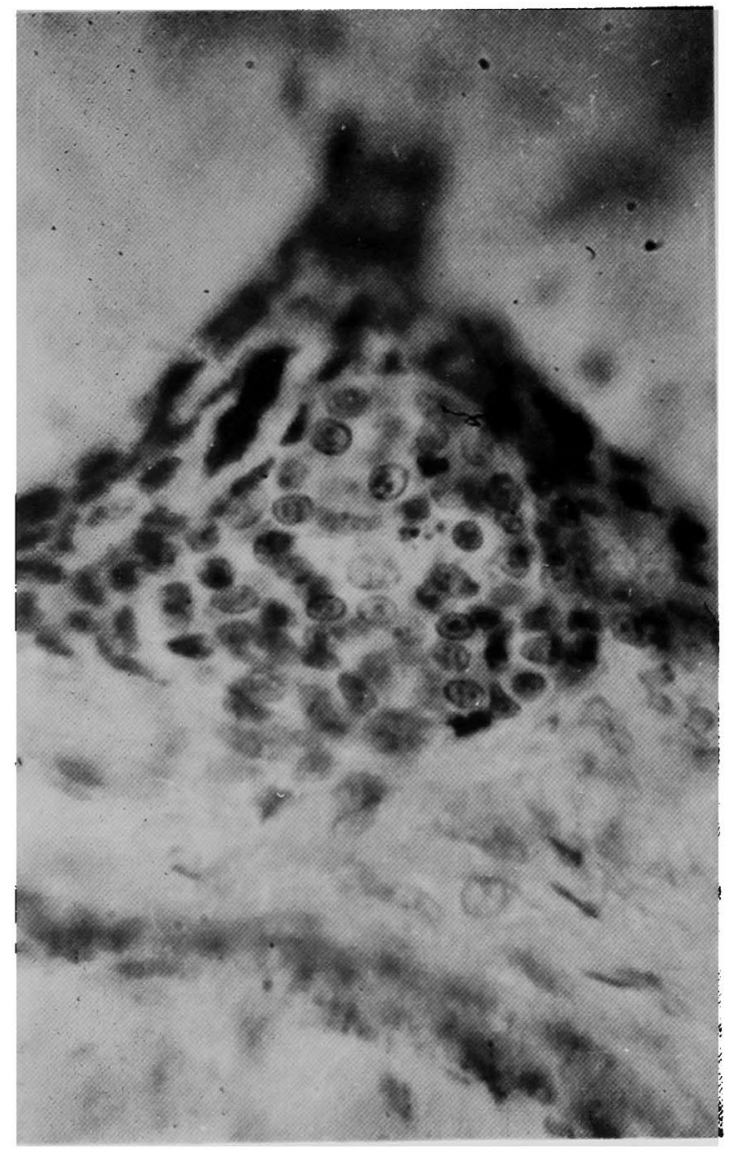

Fig. 11

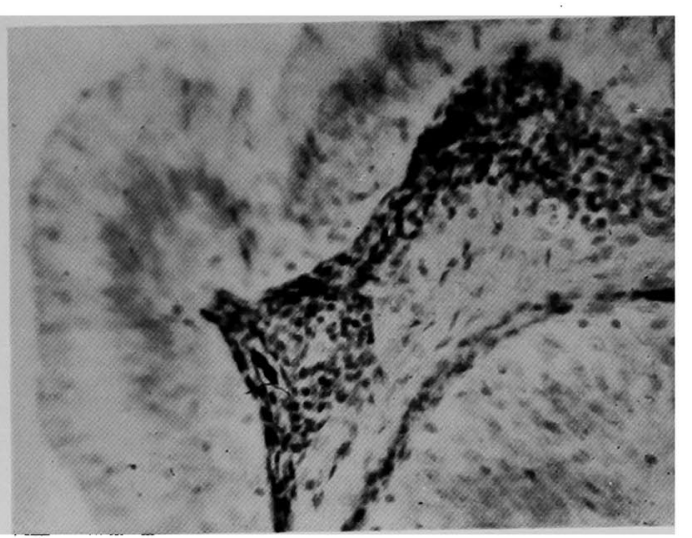

Fig. 10

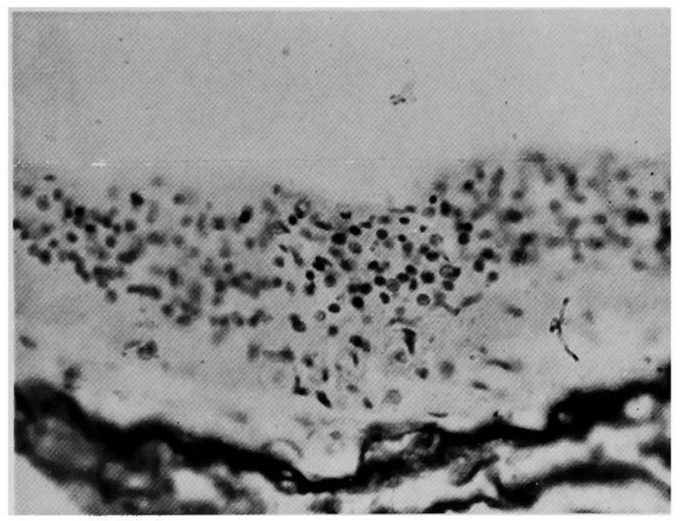

Fig. 12

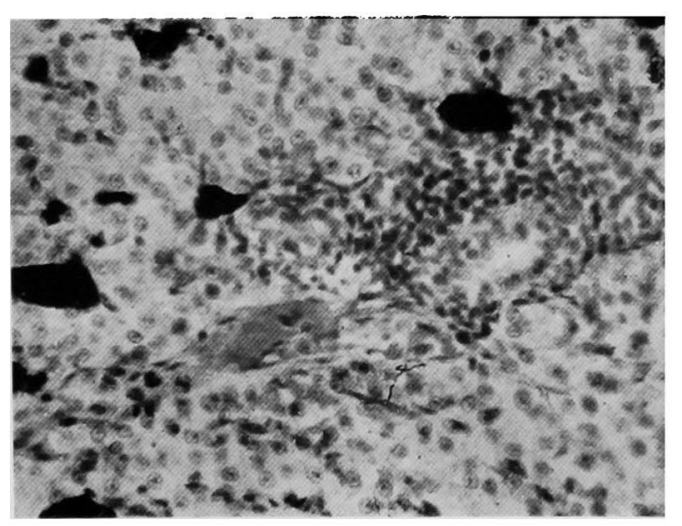

Fig. 13

M. Kotani 